Valóságos könyvtár - könyvtári valóság. Könyvtár- és információtudományi tanulmányok 2016. Szerk. Kiszl Péter, Boda Gáborné Köntös Nelli. Budapest, ELTE BTK Könyvtár- és Információtudományi Intézet. 2017. 213-215.

\title{
A FEJEZET TANULMÁNYAI ELÉ
}

\section{BÉNYEI MIKLÓS}

Debreceni Egyetem, címzetes egyetemi tanár

Nagyon köszönöm a szerkesztőknek, személy szerint Kiszl Péter intézetigazgató, doktori programvezető úrnak, kedves kollégámnak az igazán megtisztelő felkérést, a lehetőséget, hogy részben kívülállóként írhatok bevezetô sorokat a Valóságos könyvtár - könyvtári valóság címú kötet jelen fejezetéhez. Részben kívülálló - mondom -, mert valójában idetartozónak érezhetem magam. Hiszen valamikor - az idén volt ötven éve - az ELTE Könyvtártudományi Tanszékén szereztem a könyvtáros oklevelet, majd kicsit később az egyetemi doktori címet. Azóta is folyamatos a kapcsolatom az egykori alma materrel. Hajdan kiváló, legendás oktatóim voltak, elég talán Kovács Máté professzor úr, aztán Fülöp Géza és Szentmihályi János nevét említeni. S még egy negyedik tanáromra is érdemes most emlékezni: az akkor még ifjú Horváth Tiborra, aki aztán kollégám és - merem remélni, ô is úgy érezte - barátom lett. Sokat köszönhetünk neki is mindannyian, hiszen nagyon sokat tett a magyarországi könyvtári kultúra fejlesztéséért, a számítógépesítés és az informatikai szemlélet hazai meghonosításáért; egyik szerkesztője volt - a magyar könyvtárosok másik ikonjával, Papp Istvánnal együtt - a nemzetközi rangú Könyvtárosok kézikönyve öt kötetének. Tőle olvastam egyszer - nem szó szerint idézem -, hogy a könyvtár létrejötte óta a társadalom, a kultúra állandó, elszakíthatatlan része, de hogy az is maradjon, mindig változnia kell. (Akár mottója is lehetne a jelen kötet alapját képező intézeti konferenciának.) Most éppen egy ilyen változó korban élünk. Úgy hiszem, hogy annak idején, fél évszázada hasznos, korszerű ismereteket sajátíthattunk el az egyetemen. Ezt későbbi pályánk is igazolta. Ennek tudatában izgalmas szellemi kalandot ígérnek a következő dolgozatok, hiszen hajdani diákkorom ismereteit szembesíthetem azzal, hogy mi jelenleg a korszerű a könyvtár- és információtudományban, illetve a könyvtári gyakorlatban.

Az immár másodszor megszervezett kétnapos konferencia előadásaiból készült kötet jelentékeny hozadéka az egész magyar könyvtárügynek, a nem is olyan kis szakmánknak (hiszen közel négyezer könyvtárban mintegy nyolcezer ötszáz könyvtáros dolgozik). Hozzájárulhat a könyvtárosképzés továbbfejlesztéséhez, valamint a könyvtár- és információtudomány rangjának emeléséhez, tudomány voltának szilárdabb elismertetéséhez. E tekintetben különösen sokat ígér e fejezet tartalma.

Mi, könyvtárosok saját tudományterületünkön hosszú ideig legfeljebb egyetemi, közkeletű jelöléssel ún. kisdoktori címet szerezhettünk. A tudományos minősítést - kandidátusi, nagy ritkán tudományok doktora (az ún. nagydoktori) fokozatot - csak kerülő úton, többnyire másik szakunk révén nyerhettünk. Nagy vívmány, hogy a tudományos minôsítés új rendszerében a volt kandidátusi címmel egyenértékű PhD fokozat meg- 


\section{BÉNYEI MIKLÓS}

felelő teljesítménnyel közel húsz esztendeje elérhető. Az ELTE Irodalomtudományi Doktori Iskolában önálló Könyvtártudományi Doktori Program múködik, ahol közel félszázan doktoráltak. S ha ehhez hozzáadjuk a Debreceni Egyetem Számítástudományok, majd Informatikai Doktori Iskoláján elnyert néhány doktori címet, ez a szám bőven meghaladja az ötvenet. Örüljünk ennek a lehetőségnek, és legyünk büszkék sikeres kollégáinkra! Csendben, halkan azért megjegyezném, hogy MTA doktora, vagyis az ún. nagydoktori cím könyvtár- és információtudományból még mindig nem szerezhetô, itt még mindig a kerülő úton kell járnunk.

A fejezetben kilenc tanulmány olvasható, nyolc munkahelyről. Már az intézményi összetétel is sokszínú. Ketten a Fővárosi Szabó Ervin Könyvtárból publikálnak, egy fő képviseli az MTA Könyvtár és Információs Központot. Szintén egy kolléga a Magyar Képzőművészeti Egyetem Könyvtár, Levéltár és Művészeti Gyűjtemény nevű intézményt; van közkönyvtári jelölt is (a pécsi Csorba Győző Könyvtárból); szerepel a Budapesti Ügyvédi Kamara szolgáltatási igazgatója, a Magyar Nemzeti Digitális Archívum és Filmintézet korábbi osztályvezetője, továbbá a kevésbé ismert Magyar Információtudományi Alapítvány elnöke; és minden bizonnyal komoly érdeklődést vált ki az Emberi Erőforrások Minisztériuma Kultúráért Felelős Államtitkárságának egykori vezetô tanácsosa. Noha a közremúködők különböző szakterületekről érkeztek, két fontos közös vonás is megfigyelhető: egyfelől - magától értetődően - mindenki az ELTE Könyvtártudományi Doktori Programjának hallgatója, másfelől a jó felkészültségrôl tanúskodó, igényes, szép tanulmányok sokoldalúan és egyértelmúen bizonyítják a könyvtár- és információtudomány multidiszciplináris jellegét.

Sorrendben haladva: mindjárt az első szerző ilyen irányból közelít témájához; ő a tudományos kommunikáció fejlődését tekinti át az athéni filozófiai iskoláktól a nyomtatott és az újabb keletû folyóiratokon át az open acces létrejöttéig, azaz napjainkig. Igen jól összeállított elemzés érzékelteti a TEL (The European Library) és a Europeana portál kivételes jelentőségét a tudományos kutatásokban. Bár nálunk még nem igazán terjedt el, helyesen tesszük, ha szembenézünk az e-kölcsönzés jogi problémáival, mint ahogy ez meg is történik. Rögtön utána egy másik jogi-közigazgatási feladat, a felhasználóazonosítás megoldásának kérdéseit ismerhetjük meg. Mindannyian feszült figyelemmel kísérhetjük a könyvtári stratégiai programok osztályozásáról és elemzéséről, a stratégiai szemléletmód elterjedéséról írottakat. Aztán ismét külföldi információkkal folytatódik a sor: a balti államok egyetemeinek vezetőivel készített riportok alapján kapunk képet a magánszféra, az egyetemek és a könyvtárak közötti információáramlás ottani sajátosságairól. A lassan-lassan meghonosodó menedzsmenteljárás, a coaching könyvtári alkalmazásának mibenlétérôl és lehetôségeiről szintén megszívlelhető dolgokat olvashatunk. Még inkább közeledve a könyvtári munka mindennapjaihoz, biztató sorok születtek az új nemzetközi katalogizálási szabvány, az RDA alkalmazásának, webes fejlesztésének akár már közeli jövőjéről. Talán még konkrétabb az utolsó szerző, aki a sajátos könyvtári dokumentumok, a képek gépi feltárásának elméleti és gyakorlati kérdéseit boncolgatja. 
A fentiekből világosan kiderül: a doktoranduszok könyvtár- és információtudományi vizsgálódásainak egyik sarkalatos kérdése az elektronizáció, az informatikai kutatások eredményeinek könyvtári hasznosítása. Feltétlenül kiemelendő erény, hogy valamennyi munka törekszik az elmélet és a gyakorlat egységének, összhangjának megteremtésére, kifejezésére.

Ez a fejezet sokat igér, és sokat ad: valóban arról értesülünk, hogy a könyvtárügyben manapság mi a korszerü. Szakmai izgalommal várjuk a hírt a disszertációk benyújtásáról és megvédéséről. Bízunk benne, hogy kollégáink a PhD fokozat megszerzése után is töretlenül, lankadatlanul folytatják a kutatást. 